\title{
Lectin Binding Studies on Murine Peritoneal Cells: Physicochemical Characterization of the Binding of Lectins from Datura stramonium, Evonymus europaea, and Griffonia simplicifolia to Murine Peritoneal Cells ${ }^{1}$
}

\author{
JERZY PETRYNIAK,* THOMAS K. HUARD, † GERALD D. NORDBLOM, \\ AND IRWIN J. GOLDSTEIN*
}

\author{
*Department of Biological Chemistry, $\dagger$ Department of Internal Medicine, and \\ $\ddagger$ Department of Pathology, University of Michigan, Ann Arbor, Michigan 48109
}

Received July 22, 1985

Purified ${ }^{125}$ I-labeled lectins from Datura stramonium, Evonymus europaea, and Griffonia simplicifolia ( $\mathrm{I}-\mathrm{B}_{4}$ isolectin) were used to analyze changes in the expression of carbohydrates on the surface of resident $(\mathrm{PC})$ and thioglycollate-stimulated murine (C57B/6J) peritoneal exudate cells (PEC). The lectins from D. stramonium, E. europaea, and $G$. simplicifolia $\mathrm{I}-\mathrm{B}_{4}$ bind specifically to $\mathrm{PEC}$ with relatively high affinity $\left(K_{d}=5.65\right.$ $\pm 1.08 \times 10^{-7} \mathrm{M}, 1.08 \pm 0.12 \times 10^{-8} \mathrm{M}$, and $1.33 \pm 0.15 \times 10^{-7} \mathrm{M}$, respectively). Assuming a single lectin molecule binds to each cell surface saccharide, the number of receptor sites per cell ranged for different cell samples from 22.3 to $50.0 \times 10^{6}$, from 3.8 to 4.8 $\times 10^{6}$, and from 2.0 to $16.8 \times 10^{6}$ for $D$. stramonium, E. europaea, and G. simplicifolia $\mathrm{I}-\mathrm{B}_{4}$ lectins, respectively. There were approximately 3- to 7-fold, 16- to 20-fold, and 2to 20 -fold increases in binding capacity for D. stramomium, E. europaea and G. simplicifolia $\mathrm{I}-\mathrm{B}_{4}$, respectively, compared to the binding to resident, peritoneal cells. Scatchard plots of the binding of all three lectins to PEC were linear, suggesting that the receptor sites for these lectins are homogeneous and noninteracting. The binding capacity of these lectins to PEC was unchanged after trypsin digestion of cells. The expression of carbohydrates on the surface of $\mathrm{PEC}$ was also monitored by an agglutination assay. PEC were agglutinated by all three lectins whereas $\mathrm{PC}$ either were not agglutinated or were agglutinated only at high lectin concentrations. On the basis of our knowledge of the carbohydrate binding specificity of the $D$. stramomium and $G$. simplicifolia $\mathrm{I}_{-} \mathrm{B}_{4}$ lectins, we postulate that, parallel with thioglycolate stimulation, there is an increase in the number of $N$-acetyllactosamine residues and terminal $\alpha$-D-galactosyl end groups. The blood group $\mathrm{B}$, and $\mathrm{H}$ type 1 determinants-DGa1 $\alpha 1,3[\mathrm{LFuc} \alpha 1,2] \mathrm{DGa1} \beta 1,3$ (or 4)DGlcNAc and LFuc $\alpha 1,2 \mathrm{DGa} 1 \beta 1,3 \mathrm{DG} 1 \mathrm{cNAc}$, respectively, as well as DGa1 $\alpha 1,3 \mathrm{DGa} 1 \beta 1,3$ (or 4)DGlcNAc-may be considered to be possible receptors for the $E$. europaea lectin. These glycoconjugates, present on the surface of peritoneal exudate cells, provide new chemical markers for studying the differentiation of resident peritoneal cells. 1986 Academic Press, Inc.

In previous communications $(1,4)$ we reported a difference between stimulated and resident mouse peritoneal cells in the expression of carbohydate receptors. The $\alpha$-D-galactosyl-specific isolectin ( $\left.\mathrm{I}-\mathrm{B}_{4}\right)$ from

\footnotetext{
${ }^{1}$ Supported by National Institutes of Health Grant GM 29470, an Elsa U. Pardee Postdoctoral Fellowship, and American Cancer Society Grant IM 407.
}

Griffonia simplicifolia seeds (2) bound to stimulated murine PEC but not to resident $\mathrm{PC}^{2}$ as measured by a fluorescence-labeling

\footnotetext{
${ }^{2}$ Abbreviations used: BSA, bovine serum albumin; DNase I, deoxyribonuclease I from bovine pancrease; PBS, $0.01 \mathrm{M}$ phosphate buffer ( $\mathrm{pH} 7.1$ ) with $0.15 \mathrm{M}$ $\mathrm{NaCl}$ (unless stated otherwise this buffer contained 3 $\mathrm{mM}$ azide and was free of divalent cations); $P C$, resident peritoneal cells; PEC, peritoneal exudate cells;
} 
technique (1). A second lectin of complex carbohydrate binding specificity from Evonymus europaea seeds (3) was bound by murine $\mathrm{PEC}$ but not by resident $\mathrm{PC}$, as measured by an agglutination assay (4).

The primary cell population of PEC consists of macrophages. Since macrophages are involved in many immunological reactions (5), questions arise as to whether this explicit expression of differentiationrelated carbohydrates on their surface is of biological significance and whether these carbohydrates play a definitive role in some of the biological functions of these cells. Other investigators have postulated that carbohydrates are essential for macrophage-lymphokine interaction as well (68 ). Thus the expression of lectin-binding glycoconjugates on the plasma membrane of macrophages may be directly related to specific macrophage functions.

In this paper we report on the physicochemical binding characteristics of both of the above lectins, as well as a third lectin from Datura stramonium (9), to resident $\mathrm{PC}$ and stimulated PEC. These binding parameters should prove helpful in the identification, purification, and structural elucidation of the cell surface carbohydrate receptors themselves, as well as in studies of their potential function in macrophages. We have already observed that the GS I$\mathrm{B}_{4}$ isolectin can promote macrophage-tumor cell interactions leading to enhanced lectin-induced, macrophage-mediated cytotoxicity of tumor cells in vitro (10).

\section{MATERIALS AND METHODS}

Lectins. D. stramonium, $\boldsymbol{k}$. europaea, $\boldsymbol{G}$. simplicifolia $\mathrm{I}^{-\mathrm{B}_{4}}$, and $G$. simplicifolia IV lectins were purified as described earlier $(9,11-13)$.

Seeds of $D$. stramonium were obtained from Matthaei Botanical Gardens, University of Michigan; $\boldsymbol{E}$. europaea seeds were collected from wild-growing shrubs in the neighborhood of Wroclaw, Poland; and G. simplicifolia seeds were obtained from Ghana.

Carbohydrates. Methyl $\alpha$-D-galactopyranoside and lactose were products of Pfanstiehl Laboratories, Waukegan, Illinois. $N$-Acetyllactosamine was available in this laboratory from a previous study (9).

PMSF, $\alpha$-toluenesulfonyl fluoride. Trypsin-TPCK, trypsin treated with L-(tosylamido 2-phenyl)-ethyl chloromethyl ketone.
Chemicals. $\mathrm{Na}^{125} \mathrm{I}$ (carrier free) was obtained from New England Nuclear/DuPont, Boston, Massachusetts. Chloramine-T and sodium metabisulfite were from J. T. Baker Chemical Company, Philipsburg, New Jersey. Dioctyl phthalate and dibuthyl phthalate were from Aldrich Chemical Company, Inc., Milwaukee, Wisconsin; bovine serum albumin was purchased from Miles Laboratories, Napierville, Illinois. Azocoll was from Calbiochem, La Jolla, California; Bio-Gel P-60 (50-100) mesh was from Bio-Rad Laboratories, Richmond, California.

Enzymes. Trypsin-TPCK was from Worthington Biochemical Corporation, Freehold, New Jersey. Enzyme activity was checked with Azocoll as substrate according to the procedure described in the Calbiochem-Behring Catalog (1984). Deoxyribonuclease (DNase) I from bovine pancrease was from Boehringer-Mannheim Biochemicals, Indianapolis, Indiana.

Isolation and preparation of macrophages. Macrophages were isolated by peritoneal lavage as described previously (14) from C57BL/6J female mice, 4-6 weeks of age (Jackson Laboratories, Bar Harbor, Maine). Resident macrophages were obtained from normal, untreated mice while inflammatory macrophages were obtained from animals 4 days after injection with 1 $\mathrm{ml}$ sterile thioglycollate (Difco, Detroit, Mich.). The cells were harvested and sedimented at $300 \mathrm{~g}$ for $5 \mathrm{~min}$ at $4^{\circ} \mathrm{C}$. Contaminating erythrocytes were lysed in 0.17 M Tris- $0.14 \mathrm{M} \mathrm{NH}_{4} \mathrm{Cl}$ for $10 \mathrm{~min}$ at $4^{\circ} \mathrm{C}$. The cells were centrifuged (as above) and resuspended in PBS. The cells were washed twice in PBS, and reconstituted to $2 \times 10^{6} / \mathrm{ml}$ in PBS with $1 \mathrm{mM}$ PMSF.

Lectin iodination. D. strammonium and E. europaea lectins were iodinated by the chloramine-T method as described by Hunter and Greenwood (15). Briefly, the lectin (10-24 $\mu \mathrm{g}$ in $20 \mu \mathrm{l}$ of PBS) was diluted with $40 \mu \mathrm{l}$ of $0.5 \mathrm{~m}$ potassium phosphate buffer, $\mathrm{pH} 7.4$, in a 1-ml vial fitted with a multidose septum. $\mathrm{Na}^{125} \mathrm{I}(0.9-$ $1.9 \mathrm{mCi}$ ) was added followed by $30 \mu \mathrm{g}$ of chloramine$\mathrm{T}$ in $30 \mu \mathrm{l}$ of $0.05 \mathrm{M}$ phosphate buffer, $\mathrm{pH} 7.4$, and the reaction mixture was shaken for $1 \mathrm{~min}$. The iodination was quenched by the addition of sodium metabisulfite ( $10 \mu \mathrm{g}$ in $10 \mu \mathrm{l}$ of $0.05 \mathrm{M}$ phosphate buffer, $\mathrm{pH} 7.4$ ).

$D$. stramonium lectin labeled with ${ }^{125} \mathrm{I}$ was separated from the reactants on Bio-Gel P-60 (50-100 mesh), suspended in $0.01 \mathrm{M}$ potassium phosphate with 0.15 $\mathrm{M} \mathrm{NaCl}$ and 1/10,000 merthiolate, $\mathrm{pH} 7.4$, and pretreated with $5 \%$ BSA. The gel was placed in a $5-\mathrm{ml}$ disposable pipet with glass wool added to the bottom. Lectin was eluted with PBS buffer; $0.5-\mathrm{ml}$ fractions were collected. E. europaea lectin was freed from reactants by extensive dialysis against several changes of PBS.

G. simplicifolia $\mathrm{I}-\mathrm{B}_{4}$ isolectin was iodinated by the iodogen procedure (16) except that $\mathrm{NaI}$ was omitted from the reaction. Briefly, a vial $(1 \mathrm{ml})$ was coated with $36 \mu \mathrm{g}$ of iodogen in $\mathrm{CH}_{2} \mathrm{Cl}_{2}$, and $240 \mu \mathrm{g}$ of $G$. simplicifolia I-B, isolectin in PBS was added. The mixture was shaken for $5 \mathrm{~min}$ in an ice-water bath. 
The iodination reaction was stopped by removing the reaction mixture from the vial. The lectin was separated from the reactants on a Bio-Gel P-60 column prepared as above. This iodination procedure resulted in lectin with a specific activity of $5.3 \times 10^{6} \mathrm{cpm} / \mu \mathrm{g}$.

Iodinated lectins retained their carbohydratebinding properties as indicated by the fact that binding was abolished by specific hapten inhibitors.

For binding studies, radiolabeled lectins were diluted with unlabeled lectins in order to obtain the required specific radioactivity. The specific radioactivity for $D$. stramonium was $1.97 \times 10^{5} \mathrm{cpm} / \mu \mathrm{g}$; for E. europoea, $1.15 \times 10^{6} \mathrm{cpm} / \mu \mathrm{g}$; and for $G$. simplicifolia $\mathrm{I}^{-\mathrm{B}_{4}}$ isolectin, $2.7 \times 10^{5} \mathrm{cpm} / \mu \mathrm{g}$. All binding experiments were carried out in triplicate without carbohydrate inhibitor and in duplicate with inhihitor, and the mean values were calculated. The difference between parallel results did not exceed $6 \%$.

Binding assays. Binding experiments were carried out in $1.5-\mathrm{ml}$ polypropylene microcentrifuge tubes (Curtin Matheson Scientific, Inc., Houston, Tex.) precoated with BSA by incubation for at least $1 \mathrm{~h}$ with PBS containing BSA $(10 \mathrm{mg} / \mathrm{ml}) .{ }^{125} \mathrm{I}$-Labeled lectin solutions were centrifuged before each assay for 10 min at $15,600 \mathrm{~g}$ at $4^{\circ} \mathrm{C}$, to remove traces of precipitate. The reaction mixture in a final volume of $250 \mu$ l of PBS containing $10 \mathrm{mg}$ of $\mathrm{BSA} / \mathrm{ml}$ was incubated with increasing amounts of ${ }^{125} \mathrm{I}$-labeled lectin and 5-20 $\times 10^{4}$ cells. The assay with $G$. simplicifolia $\mathrm{I}-\mathrm{B}_{4}$ isolectin also contained $0.1 \mathrm{mM} \mathrm{CaCl}_{2}$. The tightly capped tubes were rotated at $4^{\circ} \mathrm{C}$ for $1 \mathrm{~h}$ and then centrifuged for $1 \mathrm{~min}$ at top speed in an Eppendorf microfuge. Solutions were carefully overlayered with $0.15 \mathrm{ml}$ of a mixture of dioctyl phthalate and dibutyl phthalate in a ratio of $1: 1(\mathrm{v} / \mathrm{v})$ and centrifuged again for $1 \mathrm{~min}$ as above. Subsequently, the upper layer was aspirated and the oil was carefully overlayered with $1 \mathrm{ml}$ of PBS containing BSA $1 \mathrm{mg} / \mathrm{ml}$. The tubes were centrifuged, the upper layer was removed by aspiration, and the washing procedure was repeated. The radioactivity was counted in an automatic gamma counter from Tracor Analytic, Elk Grove Village, Illinois. For the E. europaea lectin the only difference in the procedure was that before addition of $0.15 \mathrm{mI}$ of oil, $1 \mathrm{ml}$ of PBS containing BSA $1 \mathrm{mg} / \mathrm{ml}$ was added and mixed (to dilute the lactose solution), and the oil was overlayered. Binding of $D$. stramonium, E. europaea, and $G$. simplicifolia lectins was determined in the presence and absence of specific hapten inhibitors: $10 \mathrm{mM} \mathrm{N}$ acetyllactosamine, $15 \mathrm{~mm}$ lactose, and $10 \mathrm{~mm}$ methyl $\alpha$-D-galactoside, respectively, ${ }^{125} \mathrm{I}$-Labeled lectins were preincubated with inhibitors for $\frac{1}{2} \mathrm{~h}$ at room temperature. These values were subtracted from the total lectin bound in the absence of inhibitors to obtain specific lectin binding.

Statistical analysis of binding data. Curves were fitted and binding parameters were estimated by a nonlinear regression method using iteratively reweighted least squares as described in BMDP Statistical Soft- ware (17). The calculations were performed on the Amdahl 5860 computer at The Computing Center of The University of Michigan using a BMDP3R program. The fitted curves were plotted according to Scatchard (18).

Trypsin digestion of PEC. Unless otherwise stated, cells were kept in plastic tubes in an ice-water bath and all solutions were at $4^{\circ} \mathrm{C}$. Trypsin solutions were freshly prepared and their activity was checked with Azocoll. The reaction mixture (final volume $0.5 \mathrm{ml}$ ) consisted of $0.01 \mathrm{M}$ Tris- $\mathrm{HCl}$ buffer, $\mathrm{pH} 7.2$, with 0.15 $\mathrm{M} \mathrm{NaCl}$ and $3 \mathrm{mM}$ sodium azide and contained up to $20 \times 10^{6}$ cells and 2.5 to $25.0 \mu \mathrm{g}$ of trypsin-TPCK. Reaction mixtures were incubated at $37^{\circ} \mathrm{C}$ for $3 \mathrm{~min}$ and quenched by transfer to an ice-water bath, and, at the same time, $5 \mu 1$ of 0.1 M PMSF was added to digested cells to quench the reaction. Six microliters $(0.12 \mathrm{mg})$ of DNase I was added to both tubes and cells were incubated at room temperature for $12 \mathrm{~min}$ until clumps of cells disappeared. Control cells without enzyme were assayed in parallel and contained $1 \mathrm{mM}$ PMSF. Control and digested cells were washed four times with $3 \mathrm{ml}$ of PBS containing $1 \mathrm{mM}$ PMSF and centrifuged each time at $700 \mathrm{~g}$ for $5 \mathrm{~min}$. Cells were counted on a Coulter counter, adjusted to the concentration required, and used for the binding studies.

No loss of cells occurred after digestion with $2.5 \mu \mathrm{g}$ of trypsin compared with control cells. However, digestion with $25.0 \mu \mathrm{g}$ of trypsin caused $47 \%$ of loss of cells.

Lectin agglutination of $P E C$. Single-cell suspensions of mouse cells $(25 \mu \mathrm{l})$ at concentrations of approximately $6 \times 10^{6}$ cells $/ \mathrm{ml}$ in PBS were mixed with $50 \mu \mathrm{l}$ of varying concentrations of lectin solution, the volume was adjusted to $100 \mu 1$ with PBS, and the mixtures were incubated for $2 \mathrm{~h}$ at $4^{\circ} \mathrm{C}$ in the 96 -well plastic tissue culture plate from Vangard International, Inc., Neptune, New Jersey. After incubation the cell suspensions were examined by phase-contrast microscopy at $128 \times$ magnification. A serological scale of 0 to ++++ was used to estimate the degree of clumping. Lectin was omitted in the control sample. For inhibition of agglutination, $100 \mu \mathrm{l}$ of the solution contained deereasing, twofold dilutions of inhibitor and lectins: D. stramonium, E. europaea, and $G$. simplicifolia I-B at concentrations of 16,16 , and $50 \mu \mathrm{g} / \mathrm{ml}$, respectively, were preincubated for $30 \mathrm{~min}$ at room temperature. The solutions were cooled at $4^{\circ} \mathrm{C}$ for $10 \mathrm{~min}$ and $25 \mu \mathrm{l}$ of PEC or PC suspension was added and mixed and agglutination was assayed.

\section{RESULTS}

\section{Binding of Lectins to PEC}

Figures $1 \mathrm{~A}$ to $3 \mathrm{~A}$ show that the specific binding of lectins to PEC increased as increasing amounts of ${ }^{125} \mathrm{I}$-labeled lectins were incubated with a constant number of 

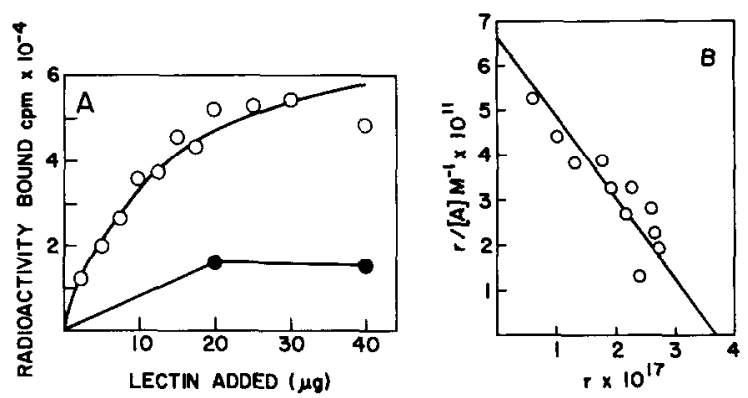

FIG. 1. Panel A: Specific bindings of ${ }^{125} \mathrm{I}-$ Datura stramonium lectin to (O) PEC and (-) PC as a function of ${ }^{120} \mathrm{~T}-D$. strumunium lectin concentration. Each point is the mean of triplicate determinations from one experiment. Points are experimental and the curve is fitted as described under Materials and Methods. SD for each point did not exceed $\pm 8 \%$ of the predicted value. Murine PEC $\left(1.19 \times 10^{5}\right)$ and murine $\mathrm{PC}\left(1.0 \times 10^{5}\right)$ were taken for binding measurements. Cells were pooled from two or three animals. Panel B: Scatchard plot of the fitted curve from panel A; $r$, moles of lectin bound per cell; [A], molar concentration of free lectin. Calculations are based on $M_{r} 86,000$ for $D$. stramomium lectin (25-27).

cells. Nonspecific binding, which represents ${ }^{125}$ I-labeled lectin not displaced by haptenic sugar, was determined in the presence of lectin-specific inhibitors (not shown). This binding was subtracted from the total binding in the absence of specific inhibitors; the resulting specific binding was saturable for all three lectins; i.e., the binding asymptotically approached a maximum value as described by the hyperbolic function which is characteristic of ligand-receptor interactions.

The specific binding was analyzed by Scatchard (18) plots (Figs. 1B-3B). The absence of curvature in the plots suggests that the carbohydrate binding sites of all three lectins are noninteracting and homogeneous. All three curves extend beyond the inflection point (half total binding) in the semilogarithmic plot (not shown) as described by Klotz (19); the data therefore provide reliable parameters for the binding capacity for these three lectins.

Free energy binding of lectins $\left(\Delta G^{\circ}\right)$ at $4^{\circ}(\mathrm{pH} 7.1)$ to $\mathrm{PEC}$ was calculated from the association constants and are shown in Table I. Among the three lectins studied, the highest $\Delta G^{\circ}$ was found for the $E$. europaea lectin $(-10.1 \mathrm{kcal})$ and the lowest $(-7.9 \mathrm{kcal})$ for the $D$. stramonium lectin.

\section{Binding of ${ }^{125}$ I-Datura stramonium Lectin to $P C$ and PEC}

Specific binding of the ${ }^{125} \mathrm{I}-D$. stramonium lectin to $\mathrm{PC}$ and $\mathrm{PEC}$ is shown in Fig.
1A. The nonspecific binding of lectin to cells was determined in the presence of 10 mM $N$-acetyllactosamine and represented $\leqslant 23 \%$ of total binding to PEC (not shown). The average dissociation constant $\left(K_{d}\right)$ was determined to be $5.65 \pm 1.08 \times 10^{-7} \mathrm{M}$ and the number of binding sites per cell, assuming a single lectin molecule binds to each receptor, was calculated to be 22.3 $\pm 1.9 \times 10^{6}$ per cell (Table II). The number of receptor sites per cell ranged from 22.3 $\times 10^{6}$ to $50.0 \times 10^{6}$ for different cell samples, a 2.2-fold variation. The PEC had more receptor sites for this lectin than any of the three lectins studied.

Binding of $D$. stramonium lectin to resident (PC) was only 15 to $33 \%$ of that determined for the stimulated cells (PEC) as seen when comparing the highest and lowest numbers of receptor sites on PEC for D. stramonium lectin (Fig. 1A, Table II). Thus, stimulation of $\mathrm{PC}$ with thioglycollate resulted in approximately a 3- to 7-fold in-

TABLE I

BINDING of LeCtins to MuRINe PEC: Association CONSTANTS $K_{a}$ AND $\Delta G^{\circ}$, AT $4^{\circ} \mathrm{C}$ AND pH 7.1

\begin{tabular}{lrr}
\hline \multicolumn{1}{c}{ Lectin } & $\begin{array}{c}K_{a} \\
\left(\mathrm{M}^{-1}\right)\end{array}$ & $\begin{array}{r}\Delta G^{\circ} \\
(\mathrm{kcal})\end{array}$ \\
\hline Datura stramonium & $1.8 \times 10^{6}$ & -7.9 \\
Evonymus europaea & $9.2 \times 10^{7}$ & -10.1 \\
Griffonia simplicifolia $\mathrm{I}^{-\mathrm{B}_{4}}$ & $7.5 \times 10^{6}$ & -8.7 \\
\hline
\end{tabular}


TABLE II

RECEPTOR Density PER STIMULATED CELl FOR Datura stramonium, Evonymus europaea, AND

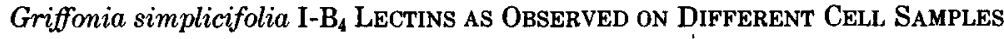

Number of receptors per cell

\begin{tabular}{cccc}
$\begin{array}{c}\text { PEC sample } \\
\text { number }\end{array}$ & D. stramonium & E. europaea & $\begin{array}{c}\text { G. simplicifolia } \\
\text { I- } \mathrm{B}_{4}\end{array}$ \\
\hline $1^{a}$ & $22.3 \pm 1.9 \times 10^{6}$ & $4.8 \pm 0.2 \times 10^{6}$ & $16.8 \pm 0.8 \times 10^{6}$ \\
$2^{b}$ & $50.0 \pm 0.3 \times 10^{6}$ & $3.9 \pm 0.1 \times 10^{6}$ & $4.0 \pm 0.3 \times 10^{6}$ \\
$3^{b}$ & $41.4 \pm 0.4 \times 10^{6}$ & $3.8 \pm 0.1 \times 10^{6}$ & $2.0 \pm 0.2 \times 10^{6}$ \\
$4^{b}$ & $\mathrm{nd}^{c}$ & $3.9 \pm 0.4 \times 10^{6}$ & $\mathrm{nd}$ \\
\hline
\end{tabular}

\footnotetext{
${ }^{a}$ Data derived from a Scatchard plot of the complete curve.

${ }^{b}$ The number of receptor sites was calculated from a series of two to three points on the plateau (saturation region) of the incomplete curve and from the affinity of lectins (determined in completed, fitted curves). Thus it was possible to use, for new data, the same nonlinear regression method with reweighted least squares, as described under Materials and Methods.

${ }^{c}$ Not determined.
}

crease in the expression of the $D$. stramonium lectin's receptors on the cell surface.

\section{Binding of ${ }^{125} I$-Evonymus europaea Lectin to $P C$ and $P E C$}

Specific binding of ${ }^{125} \mathrm{I}-E$. europaea lectin to PC and PEC is shown in Fig. 2A. The nonspecific binding of lectin to cells was determined in the presence of $15 \mathrm{~mm}$ lactose and represented $\leqslant 32 \%$ of total binding to PEC (not shown). The average dissociation constant $\left(K_{d}\right)$ was determined to be
$1.08 \pm 0.12 \times 10^{-8} \mathrm{M}$ and the mean number of binding sites, assuming a single lectin molecule binds to each receptor, was calculated to be $4.8 \pm 0.2 \times 10^{6} /$ cell. The number of Evonymus lectin receptors on PEC showed little variation among individual cell samples compared to the variation in numbers of receptor sites for the $D$. stramonium and G. simplicifolia lectins (Table II).

Resident PC specifically bound small, but clearly detectable, amounts of the ${ }^{125} \mathrm{~T}-E$. europaea lectin. This represented only 5 to
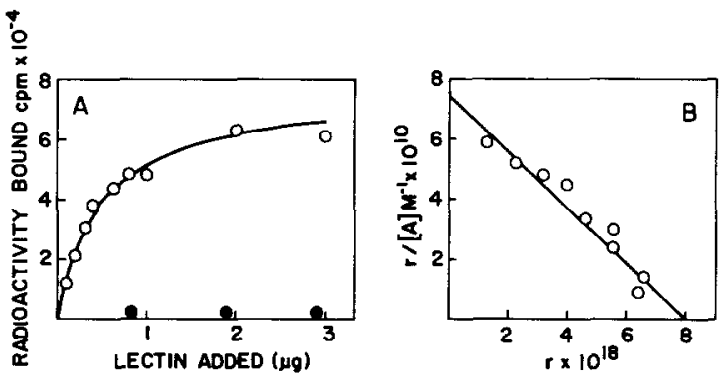

Fig. 2. Panel A: Specific binding of ${ }^{125} \mathrm{I}-$ Evonymus europaea to $(O) \mathrm{PEC}$ and $(0) \mathrm{PC}$ as a function of ${ }^{125} \mathrm{I}-E$. europaea lectin concentration. Each point is the mean of triplicate determinations from one experiment. Points are experimental and the curve is fitted as described under Materials and Methods. SD for each point did not exceed $\pm 6 \%$ of the predicted value. Murine PEC $\left(5.0 \times 10^{4}\right)$ and murine PC $\left(5.0 \times 10^{4}\right)$ were taken for binding measurements. Cells were pooled from two to three animals. Panel B: is the Scatchard plot of the fitted curve from panel A. Symbols are the same as in Fig. 1A. Calculations are based on $M_{\mathrm{r}} 166,000$ for $E$. europaea lectin (3). 
$6 \%$ of the specific binding of lectin to the inflammatory PEC. Thus, stimulation of resident $P C$ resulted in a 16 - to 20 -fold increase in the number of cell surface receptors for this lectin.

Binding of ${ }^{125} I$-Griffonia simplicifolia $I-B_{4}$ Isolectin to PC and PEC

Specific binding of ${ }^{125} \mathrm{I}-G$. simplicifolia I$\mathrm{B}_{4}$ to $\mathrm{PC}$ and PEC is shown in Fig. 3A. The nonspecific binding was determined in the presence of $10 \mathrm{mM}$ methyl $\alpha$-D-galactoside and represented $\leqslant 7 \%$ of total binding (not shown). We determined that the G. simplicifolia $\mathrm{I}-\mathrm{B}_{4}$ binds specifically to intact PEC with relatively high affinity $\left(K_{d} 1.33\right.$ $\left.\pm 0.15 \times 10^{-7} \mathrm{M}\right)$ and the mean number of binding sites was calculated to be $16.8 \pm 0.8$ $\times 10^{6}$ per cell (Table II). The variation in the number of receptor sites from individual cell samples (Table II) was approximately 8-fold.

Specific binding of $G$. simplicifolia lectin to the resident $P C$ ranged from 5 to $42 \%$ of the specific binding of the lectin to inflammatory PEC. Thus, as seen with the other lectins, in vivo stimulation of $\mathrm{PC}$ with thioglycollate resulted in a significant increase of $G$. simplicifolia receptors (2.4- to 20 -fold) on the cell surface.

\section{Lectin Binding to Tryspin-Treated Inflammatory PEC}

Lectin binding was carried out on PEC digested with 2.5 and $25.0 \mu \mathrm{g}$ of trypsin (Figs. 4A-C). The results indicate that receptors for all three lectins appear to be trypsin resistant. Results of binding studies showed that the capacity of each lectin to bind to trypsin-treated PEC was independent of the enzyme concentration used for digestion. This 10 -fold increase in enzyme concentration was used to overcome possible resistance of receptor to enzyme digestion. However, the latter amount of enzyme caused extensive damage of cells, as observed by significant cell clumping and up to $47 \%$ loss in cell number.

\section{Lectin Agglutination of PC and PEC}

As we have previously shown, E. europaea lectin caused agglutination of PEC but not of PC (4). In comparison, it is evident from Table III that $D$. stramonium and $G$. simplicifolia $\mathrm{I}-\mathrm{B}_{4}$ lectins also agglutinate $\mathrm{PEC}$. PC were not agglutinated by $G$ simplicifolia $\mathrm{I}-\mathrm{B}_{4}$ at concentrations up to $200 \mu \mathrm{g} / \mathrm{ml}$. One sample of PC was agglutinated by a 16-fold higher Datura lectin concentration than required for agglutination of PEC, and one sample was not ag-
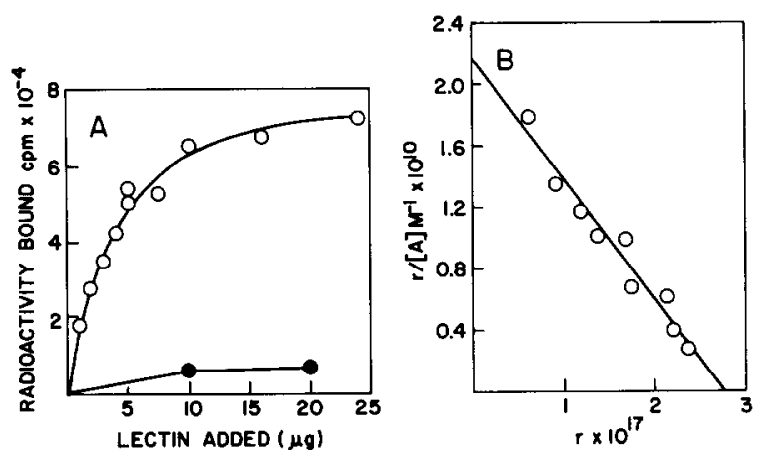

FIG. 3. Panel A: Specific binding of ${ }^{125} \mathrm{I}$-Griffonia simplicifolia $\mathrm{I}_{-} \mathrm{B}_{4}$ isolectin to (O) PEC and (e) $\mathrm{PC}$ as a function of ${ }^{125} \mathrm{I}-G$. simplicifolia $\mathrm{I}-\mathrm{B}_{4}$ lectin concentration. Each point is the mean of triplicate determinations from one experiment. Points are experimental and the curve is fitted as described under Materials and Methods. SD for each point did not exceed $\pm 5 \%$ of the predicted value. Murine PEC $\left(1.0 \times 10^{5}\right)$ and murine PC $\left(2.0 \times 10^{5}\right)$ were taken for binding measurements. Cells were pooled from two or three animals. Panel B: Scatchard plot of the fitted curve from Panel A. Symbols are the same as in Fig. 1A. Calculations are based on $M_{\mathrm{r}} 114,000$ for $G$. simplicifolia $\mathrm{I}_{-} \mathrm{B}_{4}$ isolectin (28). 

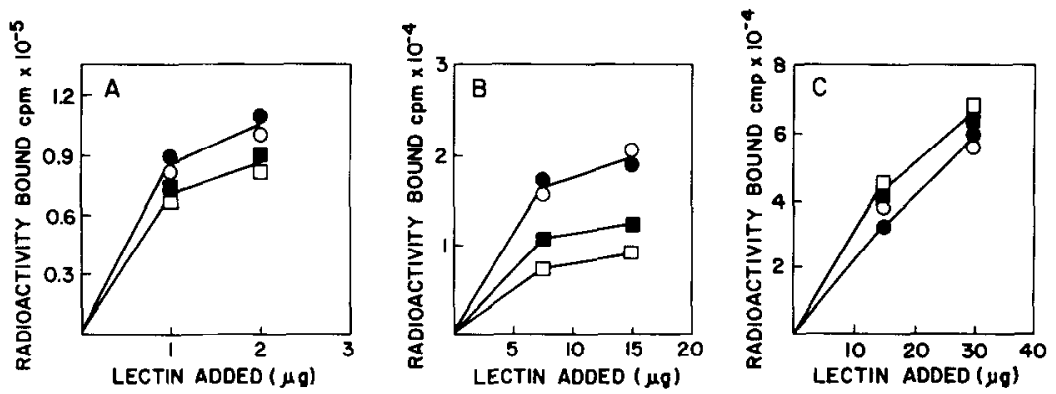

FIG. 4. Specific binding of ${ }^{125}$ I-labeled lectins to $(\square, 0)$ untreated PEC from two different cell samples and to trypsin-treated PEC with $2.5 \mu \mathrm{g}(\mathbf{E})$ and (O) $25.0 \mu \mathrm{g}$ of enzyme. Panel A: Evmymus

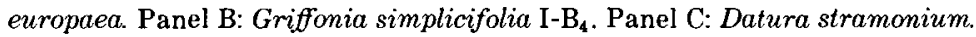

glutinated at the same lectin concentration. Agglutination of PEC was inhibited completely by $D$. stramonium- and $G$. simplicifolia I-B - $_{4}$-specific inhibitors, $7 \mathrm{~mm} \mathrm{~N}$-acetyllactosamine and $\leqslant 2.6 \mathrm{~mm}$ methyl $\alpha$-Dgalactoside, respectively.

These agglutination results on PEC and the lack or poor agglutination of $\mathrm{PC}$ by these three lectins are in agreement with the results of quantitative, binding determinations. G. simplicifolia IV lectin, which is blood group Le ${ }^{b}$ specific (13), did not agglutinate cither $\mathrm{PEC}$ or $\mathrm{PC}$ at a concentration of $348 \mu \mathrm{g} / \mathrm{ml}$.

\section{DISCUSSION}

In this study we have demonstrated a quantitative difference between resident and thioglycollate-stimulated murine peritoneal cells in the expression of carbohydrates on their cell surface as reflected by the binding of lectins from $D$. stramonium, E. europaea, and G. simplicifolia. These results are in agreement with previous observations $(1,4)$. The physicochemical parameters of binding, namely, the dissociation constant $\left(K_{d}\right)$ and the average number of receptors per stimulated cell, have also been determined.

These studies were carried out on whole peritoneal cell populations which consist predominantly of macrophages. The reason for this is that so-called "purified" macrophages actually represent a heterogenous cell population as suggested from previous observations, at least with respect to the presence of carbohydrate receptors on their surface $(1,20)$. Until suitable techniques for separations of these cell subpopulations can be worked out, the difference between a whole population of stimulated cells and a designated subpopulation cannot be evaluated.

The number of receptor sites determined in this study for each lectin is tentative

\section{TABLE III}

Agglutination of Resident and ThioglycollateStimitiatfon Mutrine Pfartonfal Cellis by Lectins

\begin{tabular}{|c|c|c|}
\hline Lectin & $\begin{array}{l}\text { Peritoneal } \\
\text { cells }\end{array}$ & $\begin{array}{c}\text { Lectin } \\
\text { concentration } \\
(\mu \mathrm{g} / \mathrm{ml})^{a}\end{array}$ \\
\hline \multirow[t]{2}{*}{$\begin{array}{l}\text { Datura } \\
\text { stramonium }\end{array}$} & Resident & $\begin{array}{r}-32 \\
32\end{array}$ \\
\hline & Stimulated & $\begin{array}{l}2 \\
4 \\
2\end{array}$ \\
\hline \multirow[t]{2}{*}{$\begin{array}{l}\text { Evonymus } \\
\text { europaea }\end{array}$} & Resident & $\begin{array}{l}>32 \\
>32\end{array}$ \\
\hline & Stimulated & $\begin{array}{l}2 \\
4\end{array}$ \\
\hline \multirow[t]{2}{*}{$\begin{array}{l}\text { Griffonia } \\
\quad \text { simplicifolia } \mathrm{I}^{-\mathrm{B}_{\mathbf{4}}}\end{array}$} & Resident & $\begin{array}{l}>200 \\
>200\end{array}$ \\
\hline & Stimulated & $\begin{array}{l}50 \\
12\end{array}$ \\
\hline \multirow[t]{2}{*}{$\begin{array}{l}\text { Griffomia } \\
\quad \text { simplicifolia IV }\end{array}$} & Resident & $>348$ \\
\hline & Stimulated & $>348$ \\
\hline
\end{tabular}

\footnotetext{
${ }^{a}$ Each number represents the result from one experiment and shows the minimal lectin concentration in the reaction mixture required for + agglutination.
} 
and can be corrected after purification of a given cell population. This represents an average number of receptors per cell. However, one has to keep in mind that lectin receptors are not uniformly distributed among particular cells; in other words, the density of receptors varies from cell to cell as was shown by de Water et al. for wheat germ agglutinin receptors on mouse peritoneal macrophages (20). The value determined for the number of receptor sites also represents the least number of receptors based on the assumption that one lectin molecule binds to one receptor; this disregards the valence of the lectins, e.g., two and four carbohydrate binding sites $/ \mathrm{mol}-$ ecule, respectively, for the $D$. stramonium and $G$. simplicifolia $\mathrm{I}^{-\mathrm{B}_{4}}$ lectins. The valence of $E$. europaea lectin has not yet been determined.

The number of receptors per cell varied from one cell sample to another. The least variance in the number of receptor sites per cell was shown for the Evonymus lectin receptor; the greatest variance was shown for the Griffomia $\mathrm{I}-\mathrm{B}_{4}$ isolectin. This variation could result from a number of factors, e.g., metabolic state or growth phase of the cell population. However, in all cases, the number of lectin receptors increased upon in vivo stimulation of the cells.

Questions which arise regarding the origin of the several- to tenfold increase in the number of carbohydrate receptor sites include: (a) Is there an increase in a subpopulation of preexisting peritoneal cells without a change in the number of receptor sites per cell? (b) Is there an increase in the number of receptor sites per cell? (c) Is there an increase in both a and $b$ ? (d) Is there a de novo synthesis of a qualitatively different species of glycoconjugate?

$E$. europaea and G. simplicifolia lectins both can react with carbohydrate determinants containing terminal $\alpha-\mathrm{D}$-galactosyl residues $(2,3)$. However, the specificity of the $E$. europaea lectin is very complex: it can react with both fucosylated (3) and nonfucosylated determinants (unpublished data, manuscript in preparation). An important question regards whether both lectins bind to the same, or to different, carbohydrate determinants on the PEC surface, and whether or not the Evonymus lectin receptor is fucosylated. Studies of Handa et al. (21) showed the presence of blood group B-active glycolipids in rat peritoneal macrophages. These glycolipids, if present in mouse macrophage membranes, might be responsible for the binding of the Griffonia and Evonymus lectins to the PEC.

Receptors for all three lectins were resistant to trypsin digestion. Incubation of cells with high concentrations of trypsin resulted in extensive damage and loss of cells. The fact that lectin binding following trypsin treatment was unchanged suggests that the receptors might be glycolipids and/or trypsin-resistant glycoproteins. This conclusion agrees with previous observations (4) which also showed that Evonymus lectin receptors were trypsin and pronase resistant. However, Maddox et al. (1) reported the sensitivity of the Griffonia lectin receptor to trypsin preparations. This is contrary to our present results. The trypsin preparations used by Maddox et al. (1) did not contain TPCK. This suggests that $G$. simplicifolia lectin receptor could be digested by contaminating proteolytic enzymes and not by trypsin itself. In support of this conclusion is our observation that the Griffonia lectin receptor was gradually destroyed during cell storage and this loss could be prevented by the addition of the proteolytic enzyme inhibitor PMSF. The binding capacity of cells stored at $4^{\circ} \mathrm{C}$ in PBS containing $1 \mathrm{~mm}$ $P M S F$ for the $G$. simplicifolia $\mathrm{B}_{4}$ isolectin was unchanged during 12 days. The receptor for $D$. stramonium lectin was very sensitive to storage, even in the presence of 1 mM PMSF. Overnight storage caused $35 \%$ loss of PEC binding capacity. In a previous report, the increased agglutinability of PEC by Evonymus lectin was also observed after trypsin and Pronase digestion (4). Inasmuch as we found that trypsin digestion did not change the lectin binding capacity of PEC one can assume that this increase in agglutinability is probably due to an increase in affinity.

One can also ask whether binding of lectin is a process restricted to the cell surface or whether it is associated with endocytosis 
and/or pinocytosis? The following observations exclude the endo- and pinocytosis of lectins: (a) lectin binding experiments were conducted at $4^{\circ} \mathrm{C}$ which abolishes both endo- and pinocytosis (22); (b) PEC agglutinated by Evonymus lectin could be dissociated after $2 \mathrm{~h}$ into single-cell suspensions by addition of specific sugar inhibitor (4). That the binding of the three lectins employed in this study, to PEC, is a cell surface-mediated phenomenon is indicated by the fact that lectin binding is abolished by specific haptenic sugars. Furthermore, digestion of PEC with coffee bean $\alpha$-galactosidase both abolished the binding of the Griffomia lectin and changed the affinity of the Evonymus lectin to PEC (unpublished data; manuscript in preparation).

Mercurio et al. (23) reported the appearance of a $\mathrm{GM}_{1}$ ganglioside species on thioglycollate- and BCG-activated macrophages, a glycolipid which was absent on resident ones. However, until its structure is determined, one cannot determine whether or not it is responsible for binding to three of the lectins we have studied.

G. simplicifolia lectin is highly specific for $\alpha$-D-galactosyl residues (1). From these results as well as from the previous observation that $\alpha$-galactosidase-treated PEC lost their ability to bind the lectin (1) we conclude that activation of PC by thioglycollate is accompanied by an increse in the number of $\alpha$-D-galactosyl residues on the cell surface. The binding of the $G$. simplicifolia $\mathrm{I}-\mathrm{B}_{4}$ isolectin to other cells (e.g., human type $B$ erythrocytes) has been studied. The dissociation constant determined in the present studies is close to those reported by Hayes and Goldstein (24). However, the number of receptor sites per cell on PEC is one to two orders of magnitude greater than on erythrocytes.

The minimal determinant for high-affinity binding to $D$. stramonium lectin is $N$-acetyllactosamine (9); therefore one can assume the presence of $N$-acetyllactosamine units (single or repeating, linear or branched) in the PEC oligosaccharides.

$E$. europaea lectin has a very complex carbohydrate binding specificity in that it can bind both fucosylated blood group
$B$ and $H$, tetra- and trisaccharides, respectively (3), as well as the nonfucosylated trisaccharide $\mathrm{DGa1} \alpha 1,3 \mathrm{DGa} 1 \beta 1,4 \mathrm{D}$ GlcNAc (unpublished data, manuscript in preparation). The Evonymus lectin shows decreasing affinity for the following structures: DGal $\alpha 1,3[\mathrm{LFuc} \alpha 1,2] \mathrm{DGa} 1-$ $\beta 1,3($ or 4 )DGlcNAc $>$ DGa1 $\alpha 1,3[\mathrm{LFuc} \alpha 1,2]-$ DGal > LFuc $\alpha 1,2$ DGa1 $\beta 1,3$ (or 4)DGlcNAc $=$ DGa1 $\alpha 1,3 \mathrm{DGa} 1 \beta 1,4 \mathrm{DGleNAc}$. Because the blood group $\mathrm{H}$ type 2 determinant (LFuc $\alpha 1,2 \mathrm{DGa} 1 \beta 1,4 \mathrm{DGlcNAc}$ ) on PEC is unlikely (4), other structures should be considered as possible receptors for the Evonymus lectin.

The carbohydrate receptors described in this communication provide new chemical markers for the various stages of PC differentiation. In order to determine the possible biological significance, if any, of the carbohydrate determinants detected by these three lectins it is of importance to determine their structure(s). These studies are in progress.

\section{ACKNOWLEDGMENTS}

The authors are indebted to Robert $H$. Kushler from The Statistical Research Laboratory of this University for computer programming and calculations and to Mrs. Lorena de Jameel for her excellent technical assistance.

\section{REFERENCES}

1. Maddox, D. E., Shibata, S., and Goldstein, I. J. (1982) Proc. Natl. Acad. Sci. USA 79, 166-170.

2. MurPhy, L. A., AND Goldstern, I. J. (1979) Biochemistry 18, 4999-5005.

3. Petryniak, J., Pereira, M. E. A., and Kabat, E. A. (1977) Arch. Biochem. Biophys. 178, 118134.

4. Petryniak, J., Dus, D., And Podwińska, J. (1983) Eur. J. Immunol. 13, 458-464.

5. VAN FURth, R. (ed.) (1980) Mononuclear Phagocytes. Functional Aspects. Parts I and II, Nijhoff, The Hague.

6. Remold, H. G. (1973) J. Exp. Med. 138, 1065-1076.

7. Amsden, A., Ewan, V., Yoshida, T., ANd CoHEn, S. (1978) J. Immunol 120, 542-548.

8. Churchill, H. W., ANd Wong, C. (1980) Cell. Immunol. 55, 490-498.

9. Crowley, J. F., Goldstein, I. J., ArnarP, J., AND LOnngren, J. (1984) Arch. Biochem. Biophys. 231, 524-533. 
10. Maddox, D. E., Goldstein, I. J., AND LoBuglio, A. F. (1982) Cell Immunol. 71, 202-207.

11. Petryniak, J., Janusz, M., Markowska, E., and LIsowskA, E. (1981) Acta Biochim Polom 28, 267-273.

12. DelmotTe, F. M., AND GoldSTein, I. J. (1980) Eur. J. Biochem. 112, 219-223.

13. Shibata, S., Goldstein, I. J., AND Baker, D. A. (1982) J. Biol. Chem. 257, 9324-9329.

14. WiCha, M. S., ANd Huard, T. K. (1983) Exp. Cell Res. 143, 475-479.

15. Hunter, W. M., AND Greenwood, F. C. (1962) $\mathrm{Na}$ ture (London) 194, 495-496.

16. FraKer, P. J., AND SPECK, J. C., JR. (1978) Biochem. Biophys. Res. Commun 80, 849-857.

17. Dixon, W. J. (ed.) (1983) BMDP Statistical Software, pp. 289-344, Univ. of California Press, Berkeley/Los Angeles/London.

18. Scatchard, G. (1949) Ann. N. Y Acad. Sci. 51, $660-672$.
19. KLоTZ, I. M. (1982) Science 217, 1247-1249.

20. de Water, R., Van't NoORdende, J. M., GiNSEl, L. A., AND DAEMS, W. T. (1981) Histochemistry 72, 333-339.

21. HaNda, E., HaNda, S., Konno, K., AND YamaKAWA, T. (1978) J. Biochem. 83, 85-90.

22. Steinman, R. M., Mellman, I. S., Muller, W. A., AND CoHn, Z. A. (1983) J. Cell Biol. 96, 1-27.

23. Mercurio, A. M., Schwarting, G. A., AND RoBBINS, P. W. (1984) J. Exp. Med. 160, 1114-1125.

24. Hayes, C. E., and Goldstern, I. J. (1975) J. Biol. Chem. 250, 6837-6840.

25. Kilpatrick, D. C., AND YeOMAN, M. M. (1978) Biochem. J. 175, 1151-1153.

26. Desai, N., Allen, A. K., AND Neuberger, A. (1981) Biochem. J. 197, 345-353.

27. Crowley, J. F., AND GoldSTEIN, I. J. (1981) FEBS Lett. 130, 149-152.

28. Hayes, C. E., ANn Goldstein, I. J. (1974) I. Riol. Chem. 249, 1904-1914. 